\title{
Revisiting Doing Business in the Middle East
}

\author{
David E. Desplaces
}

Nancy K. McIntyre

\begin{abstract}
7 his case engages students on a number of issues common to doing business in other countries, specifically in the Middle East. It is intended to be a basis for class discussion rather than to illustrate either effective or ineffective handling of the situation. The case seeks to integrate issues of international management and cross-cultural conflict and negotiation. Students are challenged to diagnose a cross-culturally sensitive situation and develop solutions in a team environment under limiting time restraints. This case is also designed to belp students understand the cultural aspects of a situation and bow different solutions could have major consequences on the bottom line of a company.
\end{abstract}

Aboard an Offshore Services Contractor's (OSC) flagship somewhere in the Arabian (Persian) Gulf, the captain and crew, as well as two other support vessels owned by OSC, were busy offloading fuel. It was the middle of the night. While the fuel was actually intended for an offshore drilling rig owned by the government of one of the most fundamentalist Islamic and radical countries in the region, offloading the fuel and selling it to smugglers had been a profitable business venture for OSC for quite a while.

In fact, over the years, the company had successfully offloaded more than 745,000 gallons of fuel worth close to $\$ 500,000$. The captains of all three ships, along with all of the crew members had received money for either actively taking part in the embezzling scheme or for looking the other way when the offloading took place. Although they felt that the risk was worth the payoff, the crew knew that they risked being charged with contraband. They also understood that if they were caught, according to Islamic law, custom's regulations and international law, it would mean that they would risk losing all of the assets of OSC, and might also receive stiff prison terms under horrific conditions.

As the captain scanned the water watching for Coast Guard vessels that regularly patrolled the Arabian Gulf waters, he thought about all of the stories he had heard of boats that had been boarded and searched by the various Coast Guards of countries in the Middle East-stories that included the loss of the cargo, the seizure of the ships, and even imprisonment for the captain and crew. He knew that getting fired by OSC was the least of his worries. What concerned him even more was that if he and his crew members were caught stealing the fuel, they risked being punished under the regulations of Sharia, often referred to as Islamic law. This punishment could include fines, imprisonment, mutilation (i.e., the cutting off of their hands), and even death.

A few hours later, the lights of the Coast Guard vessels scanned the deck of the OSC vessels, and began the process of seizing both the vessels and the cargo.The captain realized that he and his crew might have just made the biggest mistake of their lives. Although he could not get a signal on his cell phone and thus could not contact the CEO of OSC, he hoped that his boss would hear the news soon and come to the rescue of the crew of the three vessels that were now being seized.

\section{Offshore Service Company}

Offshore Service Company (name disguised) was formed to provide ships to service offshore drilling platforms. OSC was the brainchild of DJ (name disguised), a 59-year-old British national who had been living and working as a civil engineer in the Middle East for 25 years. DJ worked hard to build both his business and his reputation in the petroleum service industry. He was now living in Dubai, the economic capital of the United Arab Emirates (UAE) in the Arabian Gulf. Recognizing the growing need of large petroleum companies for expert offshore and marine support services, DJ formed the company in 1977 . With the help of a local partner, DJ created OSC as an integrated service provider of a range of products and services for oil, gas, and petrochemical companies (mostly providing support and resupplying drilling rigs on the seas).

Although DJ was now the managing partner of a large, successful company, his company had humble beginnings. DJ and his partner had started their operation by subleasing three tugboats and three barges to local petroleum companies that wanted short-term commitments to such equipment. Over the years, he watched his business grow to a fleet of many ships, including five tugboats, seven supply/utility ships, two platforms, two barges, and various support ships, 
all of which were partially owned by subsidiaries of the company. All of the ships were owned on a lease-to-purchase agreement, and required full insurance coverage to protect the value of the investment.At the time of the smuggling incident, OSC employed more than 340 staff and crew members from 19 different countries.As the company grew, DJ expanded OSC's customer service territory past the traditional geographic boundaries of the UAE.

The UAE is a federation of seven emirates or states. The main religion in the region is Islam and Muslims make up 96 percent (Shi'a, 16\%) with Christians, Hindus, and representing the remaining 4 percent. Although the emirates are predominately Muslim, they uphold Sharia (Islamic law) to differing degrees in their courts. For instance, in Dubai, the legal system is based on Sharia, but it incorporates elements of Western legal systems in such areas as commercial law.

One expansion outside of the UAE occurred when DJ decided to do business with the government-owned oil company (referred to as GOOC) in one of the Islamic and radical countries of the region. Although he realized that a commercial undertaking in this country might be risky (not a wellestablished business environment, strong involvement of the government in the economy, and radical views), he carefully weighed the risks and decided to initiate service offerings with GOOC. At the time of the smuggling incident, OSC's contracts with this oil company were valued at more than $\$ 17$ million and included the use of five vessels over the span of five years. Three of those vessels were now in the hands of the government of the country that was home to GOOC.

\section{A Brief Overview of Sharia}

Sharia denotes an Islamic way of life that, according to Muslims, has been derived from Islam. To Muslims, it represents the religious code for living in the same way that the Bible offers a moral system of conduct for Christians. Sharia has been adopted by many Muslims as a matter of personal conscience and in many Middle Eastern countries is enforced by the courts. While the courts in some countries have adopted all of the elements that make up Sharia, others enforce limited elements such as inheritance, banking, and contract law.

Calling Sharia "law" can be misleading, as Sharia extends beyond law. Sharia is the totality of religious, political, social, domestic, and private life. Sharia is primarily meant for all Muslims, but in some countries, it is applied to non-Muslims living in a Muslim society.The regulations of the Sharia can be divided into two groups: (1) regulations on worship and ritual duties, and (2) regulations of juridical and political nature.

With respect to the juridical and political impact of Sharia, individuals accused of a crime are not presumed to be innocent as they are in the United States. Consequently, it is customary that when people are considered suspects in a crime or litigation they are jailed regardless of the evidence, and then questioned about their involvement. Governments in many Muslim countries have been accused by the Western media of convicting people to reinforce governmental power and control public opinion, regardless of the truth or fairness to all parties. Furthermore, the leadership in some Muslim countries has been accused of supporting and harboring international terrorism, making normal economic exchanges and cooperation difficult. Therefore, economic relationships with the West have been limited by trade restrictions on economic, cultural, and political levels.

In this case, Sharia has a strong impact on how the government treats the men and on the punishment that might be meted out. In this particular country, the legal system was based on Sharia. The principles of government are stated to be justice, equality, and consultation, in accordance with Sharia. Punishments for serious crimes (stealing, drug, adultery, rape, and murder) include amputation and death by beheading, hanging, or, in rare cases, stoning (Encarta.com 2003).

The government might also have a claim on the 10 percent performance bond taken out by OSC. GOOC, and thus the government, might claim negligence on the part of OSC, and therefore be entitled to the money secured under the performance bond. The government might also make the argument that they are entitled to the vessels seized. DJ is pondering how this might affect his negotiation with the company and the customs officials upon his arrival.

\section{Existing Relationship Between OSC and GOOC}

The oil industry plays a vital role in the economic well-being of many countries in the Middle East. Oil is a source of energy and revenue, but the infrastructure to extract it requires constant investment, updating, and maintenance. Given the choices made by the country that DJ is doing business with, they have not had the benefit of international economic and technical cooperation that other countries in the Middle East have enjoyed. Due to this country's poor relationship with the West (United States and Europe), opportunities to find and enlist expert services to maintain the current industry infrastructure are limited or nonexistent because most large multinational corporations are often pressured by Western states not to conduct business with this country. Due to GOOC's involvement with the government, it is next to impossible to contract with Western companies. However, an Arab-based company with oil service expertise, such as OCS, would be the perfect fit.

In June 1999, DJ signed a five-year service contract with GOOC. The contract stipulated that OCS would provide the expertise and equipment necessary to maintain and update nine oil fields, which included five ships necessary to provide the services. Of the five ships, three were responsible for monitoring the offshore oil fields, supplying the platforms 
with food and fuel, and transporting personnel and equipment as needed. The supplying of fuel necessary to operate GOOC's platforms and offshore bases was done according to a set schedule. OCS was currently three and a half years into the contract with one and a half years to go. At the time of the smuggling incident, OSC had received $\$ 6.5$ million for services rendered, and was owed another $\$ 1.5$ million in outstanding invoices. Under contract stipulations, and as was customary in the oil production business, OCS was required to obtain performance bonds totaling 10 percent of the total contract value (more than $\$ 1$ million in this case). That money could be used by GOOC in the event OCS was negligent in its duties. Also, as customary in the industry, all ships were insured for replacement value.

In addition, at the time of the incident DJ and a partnering company were negotiating with GOOC the possibility of additional contracts to include various projects worth $\$ 60$ million for the next six years alone.

\section{DJ's Dilemma}

When DJ landed in the capital city, he was met by his local representative, Amed, who is a native of the country. A car was waiting to take DJ to meet with the OCS lawyers working the case. In an hour they would head to GOOC's corporate headquarters where they were to meet with the GOOC's operations director who was furious over the situation. The operations director had already indicated to Amed that not only did he want to keep the seized ships, he was considering refusing to pay the outstanding invoices and might call upon customs' officials to jail DJ and Amed, too.

DJ understood that this matter would not boil down to just replacing the fuel and paying a fine. He knew that under international law, illegal activity involving contraband automatically grants the government the right to seize all the assets involved, regardless of ownership. Due to the contraband activity, the ships had automatically become the property of the government. As DJ began to realize the financial impact-estimated replacement value for the ships was $\mathbf{\$ 8 . 5}$ million according to insurance policies and $\$ 1.5$ million in outstanding invoices-his blood pressure rose.

Amed confirmed to DJ that the crews had been treated well and had been provided legal representation through OSC's lawyers. However, what appeared to complicate the matter was that a third party was involved in the scheme.The party that convinced the crews to participate in the operation in the first place was the project maintenance manager for GOOC's operations. In short, one of GOOC's own employees was the ringleader and responsible for initiating the pilfering of the fuel. GOOC's operations director appeared to have been caught off guard as customs officials informed him of the allegations after the ships were seized, and he was being pressured to put the blame on OCS to avoid embarrassing GOOC and the government.

\section{What Should DJ Do?}

DJ was unsure of how to proceed. He was concerned for his crew and his equipment, worried about the future of the contract, and wondered if he would be able to leave the country at all. He realized that he needed to defuse the situation and that his company was at stake.

DJ had a number of things to consider. First and foremost, he needed to figure out how to protect his crew and get them out of jail as soon as possible. He wanted to ensure their safety and he wanted to regain ownership of his vessels. He also wanted to be sure that he could continue to do business with GOOC. For planned negotiations, like contract negotiations, DJ always spent a great deal of time preparing for the negotiation meetings. In this case, DJ had very little time to prepare.

Note: The instructor's manual is available upon request from the author at desplacesd@cofc.edu.

\section{About the Authors}

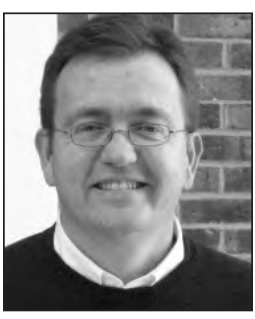

DAVID E. Desplaces (desplacesd@cofc.edu) is the director of the international business major and an assistant professor of entrepreneurship at the School of Business and Economics. He joined the College of Charleston in summer 2007 from the University of Hartford where he founded the Institute for Entrepreneurship and Economic Development and directed student community-based consulting projects in cooperation with the Connecticut Economic Gardening Group. His research has been published in the Journal of Business Ethics, Organization Management Journal, Journal of Academic Ethics, Michigan Journal of Community Service Learning, and International Journal of Case Method Research and Application.

NANCY K. MCINTYRE (Nancy.McIntyre@mail.wvu.edu) currently teaches management and organizational behavior courses for the Department of Management and Marketing at West Virginia University. Her publications have appeared in textbooks and numerous professional journals and conference proceedings including Human Relations, Journal of Organizational Behavior, Journal of Applied Social Psychology, International Journal of Learning and Intellectual Capital, Journal of Management Studies, and Organizational Dynamics.

Dr. McIntyre's current research interests include self concept-based motivation, perfectionism, and ADHD in the workplace 